\title{
Social and Cultural Integration of Senegalese Immigrants Living in Istanbul
}

\section{Sidi Boubacar DIANE ${ }^{1}$}

\begin{abstract}
This article describes the cultural and social difficulties that accompany the integration process of Senegalese immigrants, particularly those who have settled in the city of Istanbul. More specifically, it examines the immigrants' environment, their feelings, perceptions, and motivations, as well as the individual and collective strategies they use to integrate into Turkish society. Such a perspective necessarily places the individual at the center of our concerns and seeks to analyze the factors that ensure the dynamics of his or her progress in the host society.

To do this, support was taken from the concept of symbolic interactionism of George Mead (1963) an application with the experience of Senegalese settled in the city of Istanbul. It aims to try answer the following question: How do the coping strategies implemented by immigrants influence the outcome of their integration process in the host society? More precisely, how do immigrants interact with the host environment and the identity processes they develop there?

After comparing the theoretical data with the interview data of 52 Senegalese migrants in Istanbul, it was concluded that most Senegalese immigrants interact with the social and cultural references of their country of origin to integrate into the host society. Therefore, this limits their effective integration in Turkey.
\end{abstract}

Keywords Turkey, Senegal, Immigrants, Integration, Society

\footnotetext{
1 Doktora Öğrencisi, Marmara Üniversitesi, Sosyal Bilimler Enstitüsü, Radyo, Televizyon ve Sinema Anabilimdalı, sidibocar@yahoo.fr, Orcid ID: 0000-0001-7114-371X

Bu makaleye atıf için: Dıane, S. B. (2021). Social and Cultural Integration of Senegalese Immigrants Living in Istanbul. Aksaray İletişim Dergisi, 3(2), 182-200. doi:10.47771/aid.890835
} 


\section{İstanbul'da Yaşayan Senegalli Göçmenlerin Sosyal ve Kültürel Entegrasyonu}

\section{$\ddot{\mathbf{O} z}$}

Bu makalede, Türkiye'de, özellikle İstanbul'da, ikamet eden Senegalli göçmenlerin entegrasyon sürecinde kültürel ve sosyal alanlarda yaşadıkları zorluklar anlatılmıştır. $\mathrm{Bu}$ amaçla, Türk toplumuna entegrasyon aşamasındaki göçmenlerin çevresi, duyguları ve topluma yönelik algılarıyla birlikte, entegrasyonda kullandıkları bireysel ve kolektif stratejiler incelenecektir. Bireyi (göçmen) odak noktası olarak kabul eden bu bakış açısı, toplumsal kabul sürecinin dinamiğini sağlayan faktörleri analiz etmeye iter.

Bu doğrultuda İstanbul'da ikamet eden Senegallilerin durumunun incelenmesi için Georges Mead'in (1963) " sembolik etkileşimcilik » kavramı referans alınmıştır. Bu çalışmada göçmenlerin entegrasyon aşamasında kullandıkları stratejilerin, toplumsal kabul ve uyum sürecini nasıl etkilediği, özellikle göçmenlerin uyum sağlayacakları çevre ile nasıl bir etkileşim içinde oldukları ve kimliksel gelişimlerinin nasıl etkilendiği sorularına cevap verilmeye çalışılmıştır.

İstanbul'da ikamet eden 52 Senegalli göçmenle yapılan röportajlar ve teorik veriler karşılaştırıldıktan sonra, toplumsal kabul ve uyum sürecindeki Senegalli göçmenlerin çoğunun kaynak ülkenin (Senegal) sosyal ve kültürel referanslarıyla etkileşim hâlinde oldukları sonucuna varılmıştır. Bu durum, Türkiye'deki, özellikle İstanbul'daki, topluma etkin entegrasyon sürecini sınırlamaktadır.

Anahtar Kelimeler Türkiye, Senegal, Göçmenler, Entegrasyon, Toplum

\section{Introduction}

Migration is a phenomenon that involves a before and an after, it affects a multitude of elements and requires individuals who have experienced it to re-evaluate their attachment to these elements of the past to enable them to grasp the elements that are essential for integrating into society of the host country (Boltanski \& Thévenot,1991).

To study and understand the concept of the integration of migrants in their host societies, this paper intend to highlight two sections. The first one invokes the fundamental characteristics of symbolic interactionism by demonstrating, above all, the relevance of applying its postulates to 
the analysis of the social processes in which immigrants interact with the host environment to integrate into it.

Indeed, symbolic interactionism offers, through Mead's thought (1963), tools for understanding or interpreting the actions and social reactions of actors and the perceptions they have of their roles in society, which is seen as both a physical and a symbolic universe. More precisely, symbolic interactionism makes it possible to better see how immigrants interact with the host environment and the identity processes they develop about it. These processes can vary from integration, separation to maintaining a withdrawal from the cultural community of origin.

The second section leads into the phase of in-depth analysis and exploitation of the interview data. This data essentially includes the feelings, opinions, intentions, experiences, and perceptions that the 52 respondents expressed concerning the various themes that were discussed about the objective of our study. The 52 respondents were selected according to the following criteria: nationality (Senegalese), type of visa obtained in the origin country (tourist visa or student visa), average duration of 6 months in the host country (Turkey). The snowball sampling was used to reach the respondents. At this stage, he will more specifically focus on individual perspectives that will lead to bring out in the interviews, the explicit messages, and the implicit meanings that underlie them to dissect the behaviors that they represent among our respondents.

\section{The Particularities of Interactionism and its Relation to the Concept of Immigrant Integration}

The choice of symbolic interactionism theory is privileged because of its conceptual specifications inherent to the intuitive problem linked to the present research, which is based on the analysis of the adaptation strategies of Senegalese immigrants and the social interactions that accompany them. For example, interactionist theory views social communication as a central means of gradually constructing and reconstructing identity. Thus, according to this approach, identity occurs and reproduces itself both in our relationship to the other and in our relationship to society.

Indeed, social interaction presupposes that the social behavior of the individual, far from being predetermined solely by the culture, institutions, and social structures of his or her environment, derives rather from the interactions in which the individual finds himself or herself engaged and which largely guide his or her attitude, motivation, adaptation or reactions. From this point of 
view, the other's gaze, action, attitude, and reaction are considerable factors underpinning the actor's social conduct. Therefore, "whether we talk about adaptation, integration or acculturation, we can always notice that the phenomena resulting from the contact between immigrants and their host environment always refer to the notion of interaction" (Hsab, 1996:13). This notion of (social) interaction, which remains central to the interactionist approach, refers in Georges Herbert Mead (1963) to the social mechanism of actions, reactions, and adaptation of individuals to a common environment. For his part, Herbert Blumer (1969) also observes that the social activity of individuals in a society is the expression of acts elaborated by them through their interpretation of the situations in which they are placed. Hence the relevance of the interactionist concept in the theoretical orientation of the present research.

Symbolic interactionism appeared in the United States from the 1930s onwards, precisely at the University of Chicago. Inspired both by Mead's thought and teaching, this concept is based on a psycho-sociological analysis of human behavior which, according to Michel De Coster, Bernadette Bawin-Legros, and Marc Poncelet, (2001: 97): developed during the 1950s to diversify into multiple trends, the main ones being: Alfred Schütz's phenomenological sociology, Erving Goffman's theatrical model, Harold Garfinkel's ethnomethodology, Sacks' conversational analysis.

According to Boudon \& al (2003: 123), the originality of symbolic interactionism is to consider the reciprocal action of human beings and the signs that make it visible as the major social phenomenon. This same idea of reciprocal action, synonymous with interaction, appears in De Coster, Legros, and Poncelet (2001: 97).

In contrast to Mead, for whom interaction defines a meaningful, explicit, or symbolic communication; Léonetti (1990: 52), for her part, expressly designates by interaction the more or less common relations that are established between two or more social actors and which are expressed at different levels: that of representations, which are expressed in particular through the discourse of the actors, and that of interpersonal relations between individuals and groups, which can be observed in concrete face-to-face situations.

Let us recall that Mead, a pioneer of the interactionist concept, defined himself as a radical social behaviorist, who gives pre-eminence to active action in the knowledge of social reality and challenges the duality of mind and body. For him, there is no reason to set the individual against society, on the contrary, it is a question of showing their interdependence. In his main works and articles, published posthumously in 1934, under the title Mind, Self, and Society, he 
laid the foundations of the concept that was later called the Chicago School. On an epistemological level, Mead combined philosophy, sociology, and psychology to better understand the social behavior of the individual. In doing so, he is seen as one of the precursors of American social psychology. This is why symbolic interactionism is understood as a synthesis of several disciplinary references, namely philosophy, psychology, sociology, anthropology, and communication.

It should be pointed out that the term dates back to Blumer (1937) who introduced it into the literature from 1969 onwards following the English expression symbolic interactionism, but the conceptual sources to which it refers are much older (Boudon \& al. 2003:127). The classical works of Mead and later those of Goffman and other precursors claiming to be from the School of Chicago have in turn fuelled and enriched this concept. However, it should be pointed out that Mead's thoughts and work were influenced by Darwinian evolutionism, behaviorism, interactionism, and utilitarianism.

\section{Symbolic Interactionism and Communication}

Communication plays an essential role in Mead thinking because it is through communication that one first becomes aware of oneself, then identifies with others, and finally adapts to one's social environment. What Mead calls interaction or communication relates to human behavior, that is, the whole process of an individual's attitudes, actions, reactions, and social relationships. In this context, interactionist communication is understood in the sense of meaningful symbols that the individual addresses not only to others but also to himself. In doing so, "the importance of what we call communication lies in the fact that it provides a form of behavior in which the individual can become an object for himself"(Mead, 1963: 118). It follows from author's theory that there is no communication without the common and active participation of the individuals involved, without a prior relational basis between them, and a community of interests. Mead (1963: 215) provides the following clarification:

The principle that I have considered fundamental in human social organization is that of communication, which implies participation with others. This requires that the other appears in the self, that the self identifies with the other and that one becomes self-aware through the other. This participation is made possible by the kind of communication that man can achieve.

Therefore, symbolic interactionism, according to Mead, conceives communication in the sense of human interaction. The social act, which is one of Mead (1963) key concepts, serves as an analytical framework for the behavior of actors and designates the interactions of different 
actors, in particular the reciprocal adaptation of their behavior in the elaboration of the social process. Thus, the individual living in a society is always led to take part in its common activities in his or her relations with his or her entourage, and above all to adapt to them using the daily interactions maintained by all individuals. In this context, the function of communication is to maintain the social link and ensure the functioning of society.

This mutual adaptation of the interacting actors can be explained in turn by the reaction to stimuli, knowledge and common recognition of the symbol learned during socialization. This is why, in Mead's understanding, meaning refers to interpretation and fulfills an adaptive function for the actor in his relations with others.

\section{Social Integration from an Interactionist Perspective}

Perceiving society as "a symbolic universe" that presents itself to the individual as an inter-subjective world that he shares with others, symbolic interactionism views social integration from the perspective of socialization linked to the individual's social experience. Socialization defines "a process by which the child internalizes the various elements of the surrounding culture (values, norms, symbolic codes, and rules of conduct) and integrates into social life" (Cambridge english corpus, 2020). In other words, socialization refers to the fundamental process of acquiring social skills or learning the knowledge necessary to understand socially permissible roles, gestures, and attitudes. From this perspective, this process aims at transforming the individual into an active and effective member of society. Therefore, adjustment to common attitudes is a key trend in the socialization process. As Mead (1963: 135) shows:

To the extent that the child effectively adopts the attitude of others that enables him or she to determine what he or she will do about a common end, he or she becomes an organic member of society. He adopts the mores of that society by allowing the attitude of others to control his immediate expression. This implies a certain organized process.

Also, in their work, Berger and Luckmann (1986: 189) point out that socialization is never total or complete. This denotes a continuous process of internalization of social reality. This view is highlighted by Camilleri \& al (1990: 22), who states the following:

Within the networks of interaction, both family and society, which situate an individual in the world at every moment of his life, the set of traits that define him, by which he defines himself in front of others, and is recognized by them, is tirelessly constructed and reconstructed. 
In the same way that a child adopts common norms and attitudes to claim to become an active and organic member of society, in the same state of mind, the immigrant is led to adapt progressively to the mores of the host society. The difference is that immigrants who are already socialized in their countries and cultures of origin, have to integrate into a different context. From an interactionist perspective, this implies that these immigrants take into account the collective norms and values of the host society and the attitudes of its members towards them, to react to them.

Having establishing a theoretical framework, it should be recalled that, this study aims to answer the following question: How do individual coping strategies influence the social integration process of Senegalese immigrants in Istanbul? In this respect, the fundamental importance that the interactionist concept attaches to the social experience of the individual, to interpersonal interaction and interaction with the environment, to the role of otherness in access to self-awareness and the construction and reconstruction of social identity are all considerations that are of interest to our research topic.

In practice, immigrant minorities are effectively torn between the culture of origin and the host culture. A situation that often leads to identity tension at their level. In such a complex social and cultural context, Senegalese immigrants, and sub-Saharans in general, are confronted with daily situations of interaction with others and unequal social relationships from which they can hardly escape.

\section{Presentation and Analysis of the Results Obtained During Interviews with Senegalese Immigrants}

In the following lines, we will present and analyze the results we obtained from the respondents who agreed to talk to us, following our outline, and their individual experiences of adaptation to Turkish society. These results and analyses are presented following the specific research objective that we set from the outset: to explore the trajectory and influence of individual or collective adaptation strategies on the integration process. Fifty-two interviews were carried out, all of which were recorded using a smartphone and partially transcribed as they were conducted; transcription being "the operation by which the verbal content collected orally is transformed from a sound recording to a written medium" Freyssinet, (1997:167). These semi-directed individual interviews consisted of gathering the opinions of our respondents on themes we deemed relevant to our topic. 
These themes include the migration experience related to the choice to live in Turkey (Istanbul) including the motivations behind individual integration processes. The second theme focused on individual difficulties of adaptation and hence the solutions or strategies that have been adopted in the short, medium, and long term to mitigate or resolve these difficulties. The third theme consisted of collecting in turn the personal meaning that each respondent attaches to the concept of social integration and the main indicators that they associate with this concept.

\section{Characteristics of our Respondents}

It should be remembered that our sample is made up of fifty-two people, all of Senegalese nationality. Of this number, there are 36 men and 16 women, composed of couples and singles with or without children. It should be noted that these respondents are between 20 and 40 years of age. They are either students or often work in different sectors of professional activity and therefore have different levels of income.

It is also noticeable that they have mostly used tourist visas to come to Turkey, except for the 4 students who had student visas. For the 52 respondents, in their majority, Turkey was not the preferred or final destination for their migration projects. The length of their stay in Turkey varied from 9 months to 15 years at the time of the interview. 25 people out of the 52 in our sample did not have or have lost their residence permits for reasons at the discretion of the Immigration Directorate.

\section{Interview Results and Analysis}

After presenting an overall portrait of the people who were the subject of our fifty-two semi-directed interviews, we will now present the substance of the data obtained from these interviews. We will present the data collected by following the respective recommendations made by Gerald

Boutin (1997: 130-133), Sylvie (1991: 142), Mace and Pétry (2000: 103-106). These authors suggest that, based on the reading of the interviews, the researcher should make an inventory of the main ideas and recurring themes and classify them by category of information. Furthermore, based on Mace and Pétry (2000: 106), the classification of information has enabled us to obtain a structured corpus of data that will undoubtedly facilitate our analysis. In doing so, we decided to give preference and make use of interviews whose statements, or at least qualitative information, offer both recurrence and consistency with the main objective of our research. 
That being said, the presentation of the cumulative results of their analyses will selectively focus on a limited number of interviews that meet the criteria indicated above.

\section{Motivations for Leaving}

Firstly, we found it interesting to research the respondents' reasons for moving to Istanbul on a temporary or permanent basis. This revealed three main cases: the desire to go to Western Europe via the Turkish coast due to its geographical position, the ease of obtaining a Turkish tourist visa, and the dominant status of the Muslim religion in Turkey. More specifically, 30 respondents out of 52 said they decided to come to Turkey because of the ease of obtaining a visa, 15 did so because of its proximity to Europe and to go to the rich Schengen countries, while another 7 acknowledged having come because of Turkey's Muslim religious values. Beyond the reasons given, almost all (50/52) said they left their countries of origin in search of a better life than the one they had in their countries of origin. In other words, the search for a better socio-economic and educational quality of life is the main reason for their expatriation. A single mother who has been living in Istanbul with her daughter for 5 years tells us about her career path and evokes the quest for a better quality of life for her and her child:

After completing my studies for the commercial technician's certificate, I looked for a job equivalent to my training but was unsuccessful all over Senegal, but unfortunately, I didn't get it. In my country, people have different views of me as a single mother. In order not to let my social situation influence my daughter's education, I decided to give us a second chance. With my meager means, I applied for a tourist visa to go to France or Spain where I have close acquaintances. But God decided otherwise, we are still here in Turkey (Istanbul).

For the same reasons in the quest for the best living environment, a man in his thirties does not hesitate to put forward the socio-cultural and religious environment of the country to justify his preferences for Turkey. He expresses himself in these terms:

Many friends who are in other countries like France and Germany have already informed me of the reality on the ground. They cannot pray normally as the Muslim religion requires. Turkey is a Muslim country, I know that staying here allows me to work and practice my religion in peace.

Another respondent aged 33, living in Istanbul for 7 years, seems to link this choice rather to purely economic reasons: 
My friends contributed and thank God I was able to come here to Turkey. I can't spend much money on my relatives who stayed behind but I manage to support myself and I think that is the most important thing.

Another young man, this time a 29-year-old, and student who has been living in Istanbul for 6 years, explains the origin of his departure for Turkey because of the unfavorable opinions on his French visa applications:

I looked for a French visa for a many time but it was rejected, thanks to a friend who is also Senegalese, I obtained information about university studies in Turkey. After obtaining my Master's degree here in Turkey, I stayed an extra year doing odd jobs and finally got the YTB scholarship ${ }^{2}$ for the Ph.D.

In the same vein, we felt it was relevant to identify the source of motivation of our respondents concerning their adaptation efforts. For example, to the question: "Is there a particular motivation that motivates you to integrate into Turkish society today?" various answers were given, including motivations linked to the ease of doing business, finding odd jobs at least so as not to be dependent on others (19 cases), schooling and the future of the children ( 3 cases), and the level of the social and health infrastructure considered relatively satisfactory in Istanbul compared to the country of origin (15 cases). The 15 others see Turkey as a stopover on their journeys to Western European countries and therefore have no real motivation to adapt to life in Istanbul.

The words of this 24-year-old woman who has been living in Istanbul for 3 years illustrate her motivation to live and integrate into Turkish society:

Yes, of course. This is a job opportunity that is relatively easy and better paid than in my home country. By being here, I am better able to intervene financially in my family's affairs. I have to admit that the salary I receive here is much higher than what I would have received in my country. In addition, in my country it's not easy to get a job if you don't have "long arms". Why not stay here to work and earn an honest living?

Another 39-year-old male respondent, who came to Istanbul 9 years ago, focused his motivation on the future of children and in particular the health and safety framework that Turkey offers them:

\footnotetext{
2 Yurtdışı Türkler ve Akraba Topluluklar Burslari / Scholarships for Turks Abroad and Related Communities.
} 
My 2 children who study here are in a non-French-speaking environment because they study in a Turkish school; all in all, they receive a good education because everything is done here to teach the children better. That's my motivation. What I find extraordinary here in Istanbul is security. There is security in Turkey in general, there is tranquility.

Others shirk from this state of mind: peace of mind, security, easy employment, and more satisfactory remuneration than in their country of origin, by emphasizing the temporality of their stay here in Turkey. One of them expresses himself with these words:

My goal is not to stay here in Turkey, either I will go to Western Europe, or I will go back to Senegal if I manage to save some money. The Turkish currency, which is losing its value lately, does not encourage me to stay here, it is always better to have money in Euros or Dollars, at the moment we can give it to our close relatives back home.

\section{Personal Actions are Undertaken in The Integration Process}

The interviews show that the concrete actions initiated by the respondents during the first years of their settlement in Istanbul mainly include the following: concern about rebuilding a new social network in the host country, actively seeking stable employment, and speaking the Turkish language. Apart from those who originally came to Turkey to pursue their studies, the majority of respondents acknowledge that they have a long way to go to integrate into Turkish society. This is the case of this 28-year-old woman who has been living here in Turkey for 4 years:

Especially I don't have any Turkish friends and maybe I haven't even had the opportunity to make Turkish friends. In the factory where I work, we are almost all foreigners, and just after work, I go back to our flat. There we're among friends (3 Senegalese women and a Gambian woman), we only talk among ourselves in Wolof ${ }^{3}$. I've never taken Turkish language courses but I'd like to.

\section{Difficulties in Adapting to Turkish Society}

The most recurrent difficulties in social adaptation highlighted by the interviews were on four levels: difficulties in communicating in Turkish, labor market hassles and frustration, which makes it difficult for immigrants to find satisfying and rewarding jobs, and the gap if not the culture shock that most often accompanies the life of some immigrants in Turkish society.

\footnotetext{
3 Local language spoken mainly in Senegal and part of The Gambia
} 
There are also the negative attitudes of some members of the host population, including the lack of openness, mistrust, and distance that characterize their interpersonal relations towards foreigners.

Turkish language difficulties are mentioned by almost all our respondents, including students who have obtained certificates of Turkish language proficiency in university language centers. This student said:

I had a lot of difficulties learning Turkish in TOMER ${ }^{4}$. I think the problem is that we hadn't had contact with Turkish before, compared to French, English, German, Portuguese and Spanish, which are taught in Senegal as a main or secondary language.

\section{The Cultural Gap}

In the case of the cultural gap, it is the difficulty, or more precisely the incompatibility, that the immigrant deeply feels in wanting to transpose the habits acquired in the country of origin into the host environment in an intact way. A 28-year-old woman, who has lived in Istanbul since 2015, expresses her embarrassment at adapting her culinary practices to her Turkish neighborhood relations:

In Africa, strong flavors are generally used in gastronomy; for example, when preparing tchèbou-djen ${ }^{5}$, you have to use local condiments that are not often found here. Some of these condiments have strong smells in the eyes of the Turks. That's why my Turkish neighbors came to complain to me 2 times. I understand that it is not part of their eating habits but forbidding us to prepare food from home is like a feeling of exclusion for migrants.

\section{The Negative Attitudes of Some Turks towards Migrants of Sub-Saharan Origin}

The negative attitudes of the members of the host society, in this case, some Turks, generally refer to the misbehavior that characterizes their interpersonal relations, ranging from mistrust to indifference and lack of openness. This man in his forties, who has lived in Turkey for almost 15 years, is not indifferent to certain behavior on the part of some Turks and illustrates this in the following terms:

\footnotetext{
4 Türkçe Öğretim Merkezi: Turkish Language Learning Center

${ }^{5}$ A dish of Senegalese origin based on rice, seasonal vegetables etc...
} 
They can ignore you all year round, but they have no problem coming to you when they need you. Whereas in Senegal, relationships are cultivated and maintained over the long term, for the future.

Another 29-year-old migrant who came to Turkey in 2017 and noticed the negative attitude of some flat owners in his search for a residence, expresses himself as follows:

At the beginning of my prospection to find a flat, I logged on 6 to https://www.sahibinden.com/kiralikdaire but after several attempts, it was unsuccessful. They don't hesitate to tell you openly that you are a foreigner and they don't give their flats to foreigners, especially when you tell them that you are from sub-Saharan Africa. In the end, I went through the real estate agencies, with them we are lucky to get it quickly but it costs us a lot more. I had no choice.

\section{Integration Strategies}

We refer to conscious or unconscious actions, which are undertaken by immigrants facing the new realities of the host society, as integration strategies within the framework of this work. Why integration strategies? Because, in our view, they are deliberate or unintentional actions that are skillfully maneuvered by immigrants to achieve immediate or distant goals related to integration processes. These actions ultimately enable immigrants to take their place individually or collectively in the host society, including Turkish society. In the light of what was said during the interviews, it appears that our respondents have, in their integration process, undertaken some actions or implemented some solutions to alleviate the difficulties or overcome the obstacles they have faced in Turkish society. Among these strategic actions, learning Turkish in language centers or on the street, good neighborly relations with the Turkish people, reactionary withdrawal to the community of origin, and preservation of the culture of origin figure prominently. Another integration strategy that was identified in the interviews was the withdrawal to the immigrant ethnic community. This form of adaptation results, on closer inspection, from the difficulties or inability of some immigrants to develop quality contacts with the Turks. In any case, this is the tendency that emerges among the majority, which is why we felt it necessary to expose it in this work.

\section{Withdrawal and Preservation of the Culture of Origin as a strategy for Integration}

\footnotetext{
6 Site dedicated to the supply and demand of almost all new and second-hand items as well as all types of accommodation such as houses or flats.
} 
This withdrawal consists of the immigrant seeking or finding refuge in his or her ethnic community in the hope of overcoming the social isolation in which he or she finds himself or herself as a result of expatriation. Indeed, faced with the difficulties or more precisely the repeated failures to develop the desired friendly relations with the natives of the host society, the majority of Senegalese immigrants have, in most cases, no other recourse than their communities of origin. This is where they more easily acquire the necessary friends, knowledge, and resources they need in terms of support, assistance, and information exchange. 45 of our respondents fall into this category, as long as they state that all their friends come from their respective cultural communities and therefore recognize the importance of these communities in their process of integration into Turkish society.

The language, distrust on both sides, indifference, and distance that characterize the attitude of many members of the host population towards foreigners prevent many newcomers from developing lasting ties with them.

The example of this 27-year-old migrant living in Turkey three years ago shows us his attachment to his community of origin:

All my real friendships here are with my fellow countrymen, and I usually take part in the celebratory activities of my community association. But it must be said that I had no choice but to integrate into my community. As soon as I arrived here in Istanbul, I benefited from the valuable advice of the compatriots who were already here. It was through members of our community that I managed to get my first job in a factory.

The issue of the immigrant's withdrawal into his or her ethnic community has been particularly explored by the Chicago School, which sees it as an important moment in the integration process in the sense that community ties can facilitate the group's adaptation to the host society. Leading researchers at this School have attributed both a protective and an integrating role to ethnic or nationality grouping in the host country. According to them, this grouping, far from being a regression, allows immigrants to counter or minimize the disruptive or disorganizing effects of acculturation in a new and foreign environment. Because, in fact, the conflict between nationals and foreigners obliges, as a first step, stigmatized foreigners to regroup by origin. The group that is brought together will serve as protection and at the same time as a grid towards integration. (Stéphane B and Gérard N, 1991, cited by Taïeb, 1998: 202).

Interactionist theory examines the question of identity from two perspectives: interaction on the one hand, and socialization on the other. These two perspectives feed into some dominant 
psychological and sociological theses on the construction and reconstruction of identity, which in both cases results from the complex relationships between the external definition of the self and the internal perception, between the objective and the subjective, between the self and the other, between the social and the personal Lipiansky, (1990: 174).

Mead (1963: 119) sees the genesis of identity as a consequence of social activity, because, according to him, "it is not possible to conceive of a self that would develop outside of social experience." Hence the appearance of self-awareness in the behavior of the individual who acts and reacts about other members of his environment or community. In other words, the individual's ordinary social attitude consists either in resembling other members of society by imitation or in differentiating from them using differentiation. This is why, according to Mead (1963: 147), "to be self-aware is essential to become an object for oneself by one's relationships with other individuals". This is also demonstrated by Boudon \& al. (2003: 117) who, building on Mead's (1934) thinking, state that identity is not closed in on itself, but rather is the result of dynamic interactions that occur from childhood and are likely to be transformed later in larger social environments.

In practice, the strategy of retreating into the ethnic or national community shows strong tendencies to lead to a way of life that remains essentially communal. The risk to this kind of life is that it may in some cases, in addition to the lack of relations with the host population, be accompanied by a more or less desired preservation of the culture of origin. From this point of view, such a (communitarian) attitude is contrary to what we call social integration but is very similar to separation, which Berry (1991: 13) had already identified in his work on acculturation patterns.

In this context, it can therefore be deduced that the integration strategy that favors withdrawal into the community of origin most often offers an outcome that oscillates between cohabitation and separation, an outcome that is therefore contrary to social integration. This can be seen in the speech of this 26-year-old woman who came to Turkey in 2018 and who has been living in her community environment since then and who recognizes the superficial nature of her contacts with Turkish society:

My contacts with the realities of Turkey are still superficial. I live and work in Istanbul, but my whole life is still dominated by my Senegalese habits and I am more connected with Senegalese and other West African nationals than with Turks and I live here as if I were at home in Senegal. 
This respondent's views can be summed up by two clues: limited or reduced interaction with the host population and very strong community ties. The desire of these migrants to preserve their cultural heritage from their countries of origin is very perceptible in their discourse.

As for this other interviewee, aged 33, who moved to Istanbul 10 years ago, married to a compatriot (Senegalese), and works in an international delivery company owned by her husband, she sees the preservation of her culture of origin as a source of pride and self-assertion:

I am completely proud of who I am and my culture of origin. In any case, I did not come to Turkey to change my habits. When I came here, I already had a culture in which $i$ was brought up and with which $i$ define myself wherever I am. I respect the rules that allow me to live correctly and in harmony with Turkish society, but this does not mean that I have to live, think and see things in the same way as the Turks who were born and raised here.

This withdrawal into oneself is one of the characteristics of resistance to integration and has also been exposed by several researchers, particularly Didier Lapeyronnie (1993) in France and Gaby Hsab (1996) in Quebec. These authors point out that certain factors can affect the immigrant's integration process and lead him or her to develop a form of resistance "through the maintenance of ethnic identity as a frame of reference, through the lack of identification with the majority group and increased awareness of the strength of ethnicity." (Hsab, 1996: 142).

The latter strategy necessarily leads to a clear separation from the host society. In the analysis, it is legitimate to note that this type of integration strategy serves, to a certain extent, the cause of the proponents of the cultural argument of integration who argue, as Begag (2003: 51) points out, that some cultures integrate better than others. Thus, immigrants who adopt this strategy most often lead a parallel existence to the life of the host majority.

\section{Conclusion}

The issue of integration has been around since the very beginning of sociology, but the social integration of migrants, contrary to exclusion or marginalization, has really been at the heart of the debate since the 1990s, a period when globalization was taking off in leaps and bounds. The question is whether the "social divide" will not take over the life harmony in society. In contrast to other studies, adaptation strategies arising from immigrants' motivations play a key role in their integration process in the host society. Most of the research that has been conducted 
in Europe and America on the issue of immigration and integration has similarly concluded that the age of the immigrant upon arrival in the host country and the length of stay are the two most important determinants of integration.

The results of exploratory and empirical research challenge this widely held assumption by adding a significant limitation, or at least by introducing a nuance regarding the importance of age and length of stay in the host society. That said, while the data collected from our respondents allowed us to understand, describe in detail and analyze the individual logics that guide the adaptation strategies of the immigrants in question and to assess their degree of integration, they do not, however, allow the results of this research to be generalized.

In the host country, the immigrant is at the heart of a process of disorganization and reorganization, socialization, de-socialization and re-socialization throughout his or her integration. It is therefore the individual's (the immigrant's) motivations that condition his or her identity and cultural emergence in the host society. Difficulties in synchronization, misunderstandings and failures of structuring between immigrants and nationals are at the origin of communitarianism for some persons, and rejection for others. To speak about integration of immigrants is to evoke a stage (the integration or non-integration of a society, the integration or non-integration of individuals into society) or a dynamic process. In all cases, one seeks to trace the coherent insertion of individuals or groups into a larger whole. This integration process takes place thanks to factors endogenous and exogenous to the immigrant, of which the most frequently cited are: work, family or school. However, for Senegalese immigrants in Istanbul, withdrawal into the community of origin is much more recurrent. In the present study, there is a strong tendency for integration to focus on the community rather than the frequently cited ones (work, family or school).

Apart from the clarification of the role of adaptation strategies among some African immigrants in Istanbul, Turkey's most populous and cosmopolitan city, this work has done very little to address and develop the inescapable question of identity in the relations of otherness between immigrants from sub-Saharan Africa and the other components of the city's population.

\section{Bibliography}

Begag, Azouz. (2003). L'intégration: idées reçues. Paris: Éditions Le cavalier bleu : 122

Berry, Jhon. Widdup. (1991). Coûts et avantages socio-psychologiques du multiculturalisme. Ottawa: Conseil Économique du Canada : 50 
Berger, Peter \& Luckmann Thomas. (1986). La construction sociale de la réalité. Paris: Méridiens Klincksieck: 288

Blumer, Herbert. (1937). "Social Psychology," in P. Emerson, E. P. Schmidt [Eds.], Man and Society, Englewood Cliffs: Prentice-Hall

Blumer, Herbert. (1969). L'interactionnisme symbolique in Sociologie: épistémologie d'une discipline: Textes fondamentaux, sous la dir. de lean-Michel Berthelot, p. 72-76. Bruxelles: Éditions de Boeck Université.

Boudon, Raymond, Philippe Besnard, Mohamed Cherkaoui. \& Bernard Pierre Lécuver (1999). Dictionnaire de sociologie. Paris: Larousse : 279

Boltanski Luc \& Thévenot Laurent. (1991). De la justification : les économies de la grandeur. Paris : Galimard, collection Essais

Boutin, Gerald (1997). L'entretien de recherche qualitatif. Québec Presses de l'Université du Québec : 169

Cambrigde English corpus, Retrieved November 18, 2020, from:

https://dictionary.cambridge.org/dictionary/english/socialization

Camilleri, Carmel, Joseph Kastersztein, Lipiansky Edmon. Marc, Hanna Malewska-pevre, Léonetti Taboada \& Ana Vasquez. (1990). Stratégies identitaires. Paris: Presses Universitaires de France : 228

Dagenais, Sylvie. (1991). Sciences humaines et méthodologie: Initiation pratique à la recherche. Laval: Beauchemin : 163

De Coster, Michel., Bernadette Bawin. \& Marc Poncelet. (2001). Introduction à la sociologie. Bruxelles: Éditions De Boeck Université : 312

Freyssinet-Dominjon Jacqueline (1997). Méthodes de recherche en sciences sociales. Paris: Montchrestien : 356

Hsab, Gaby. (1996). Politiques d'intégration et résistances ethniques au Québec: le cas d'immigrants libanais depuis 1975. Mémoire de maîtrise, Montréal, Université du Québec à Montréal : 151

Lapeyronnie, Didier. (1993). L'individu et les minorités: la France et la Grande-Bretagne face à leurs immigrés. Paris: Presses Universitaires de France : 361 
Léonetti, Taboada. (1990). Stratégies identitaires et minorités: le point de vue du sociologue, sous la dir. de Paul Fraisse Paris: Presses Universitaires de France.: 43-83.

Lipiansky, Edmon. Marc. (1990). Identité subjective et interaction, sous la dir. de Paul Fraisse, p. 173-213. Paris: Presses Universitaires de France : 43-83

Mace, Gordon \& Pétry, François. (2000). Guide d'élaboration d'un projet de recherche. Québec: Presses de l'Université Laval; Paris: De Boeck Université: 134

Mead, Georges. Herbert. (1963). L'Esprit, le soi et la société. Paris: Presses Universitaires de France : 332

Taïeb, Eric. (1998). Immigrés: l'effet génération: Rejet. Assimilation. Intégration d'hier à aujourd'hui. Paris: Les éditions de l'atelier : 399 